\title{
Estimating Aboveground Biomass on Private Forest Using Sentinel-2 Imagery
}

\author{
Askar ${ }^{D},{ }^{1}$ Narissara Nuthammachot $\left(D,{ }^{1}\right.$ Worradorn Phairuang, ${ }^{1}$ Pramaditya Wicaksono, ${ }^{2}$ \\ and Tri Sayektiningsih ${ }^{3}$ \\ ${ }^{1}$ Faculty of Environmental Management, Prince of Songkla University (PSU), 90110 Songkhla, Thailand \\ ${ }^{2}$ Cartography and Remote Sensing, Faculty of Geography, Gadjah Mada University, 55281 Yogyakarta, Indonesia \\ ${ }^{3}$ Research and Development Institute for Natural Resource Conservation Technology, Ministry of Environment and Forestry \\ of Indonesia, 76112 East Kalimantan, Indonesia
}

Correspondence should be addressed to Narissara Nuthammachot; narissara.n@psu.ac.th

Received 15 May 2018; Revised 28 August 2018; Accepted 30 September 2018; Published 16 December 2018

Academic Editor: Franz L. Dickert

Copyright (C) 2018 Askar et al. This is an open access article distributed under the Creative Commons Attribution License, which permits unrestricted use, distribution, and reproduction in any medium, provided the original work is properly cited.

Private forests have a crucial role in maintaining the functioning of the Indonesian forest ecosystem especially because of the continuous degradation of natural forests. Private forests are a part of social forestry which becomes a tool for the Indonesian government to reduce carbon dioxide $\left(\mathrm{CO}_{2}\right)$ emission by $26 \%$ by 2030 . The United Nations Programme on Reducing Emissions from Deforestation and Forest Degradation has encouraged the Indonesian government to establish a forest monitoring system by estimating forest carbon stock using a combination of forest inventory and remote sensing. This study is aimed at assessing the potential of vegetation indices derived from Sentinel-2 for estimating aboveground biomass (AGB) of private forests. We used 45 sample plots and 7 vegetation indices to evaluate the ability of Sentinel-2 in estimating AGB on private forests. Normalised difference index (NDI) 45 exhibited a strong correlation with AGB compared to other indices $\left(r=0.89 ; R^{2}=0.79\right)$. Stepwise linear regression fitted for establishing the model between field AGB and vegetation indices $\left(R^{2}=0.81\right)$. We also found that AGB in the study area based on spatial analysis was $72.54 \mathrm{Mg} / \mathrm{ha}$. A root mean square error (RMSE) value from predicted and observed AGB was $27 \mathrm{Mg} / \mathrm{ha}$. The AGB value in the study area is higher than the AGB value from some of forest types, and it indicates that private forests are good for biomass storage. Overall, vegetation indices from Sentinel-2 multispectral imagery can provide a good result in terms of reporting the AGB on private forests.

\section{Introduction}

The Indonesian tropical forest is home to myriad flora and fauna, including charismatic species such as orangutans (Pongo pygmaeus), Sumatran tigers (Panthera tigris sumatrae), and rhinos (Rhinoceros sondaicus) [1-4]. Unfortunately, the Indonesian tropical forest is under threats due to degradation and deforestation. In a time span of a decade from 2000 to 2010, 14.7 Mha of Indonesian tropical forests has disappeared [5]. Sumatra, during 1990-2010, lost 7.54 Mha of its primary tropical forests [6], and, likewise, Kalimantan between 1996 and 2002 lost nearly 3 Mha of forest cover [7]. Many factors are blamed for triggering deforestation such as inappropriate transmigration policy, mining, and palm oil expansion and the increase in agricultural areas [8].
Deforestation in Indonesia is eventually becoming a global concern. This phenomenon has not only driven Indonesia to lose forest areas but also increased the greenhouse gas (GHG) emission, which in turn can lead to the accumulation of GHG in the atmosphere. Majority of $\mathrm{CO}_{2}$ emission in Indonesia is from land use, land use change and forestry (LULUCF) sectors [9]. In response to that, the Indonesian government through the $21^{\text {st }}$ of Conference of the Parties (COP) in Paris has committed to reducing $\mathrm{CO}_{2}$ emission at $29 \%$ by 2030 [10]. One of the strategies applied to achieve the goal is through social forestry development [10].

Based on the Ministry of Environment and Forestry regulation, social forestry in Indonesia can be divided into six parts including hutan tanaman rakyat (people's planting 


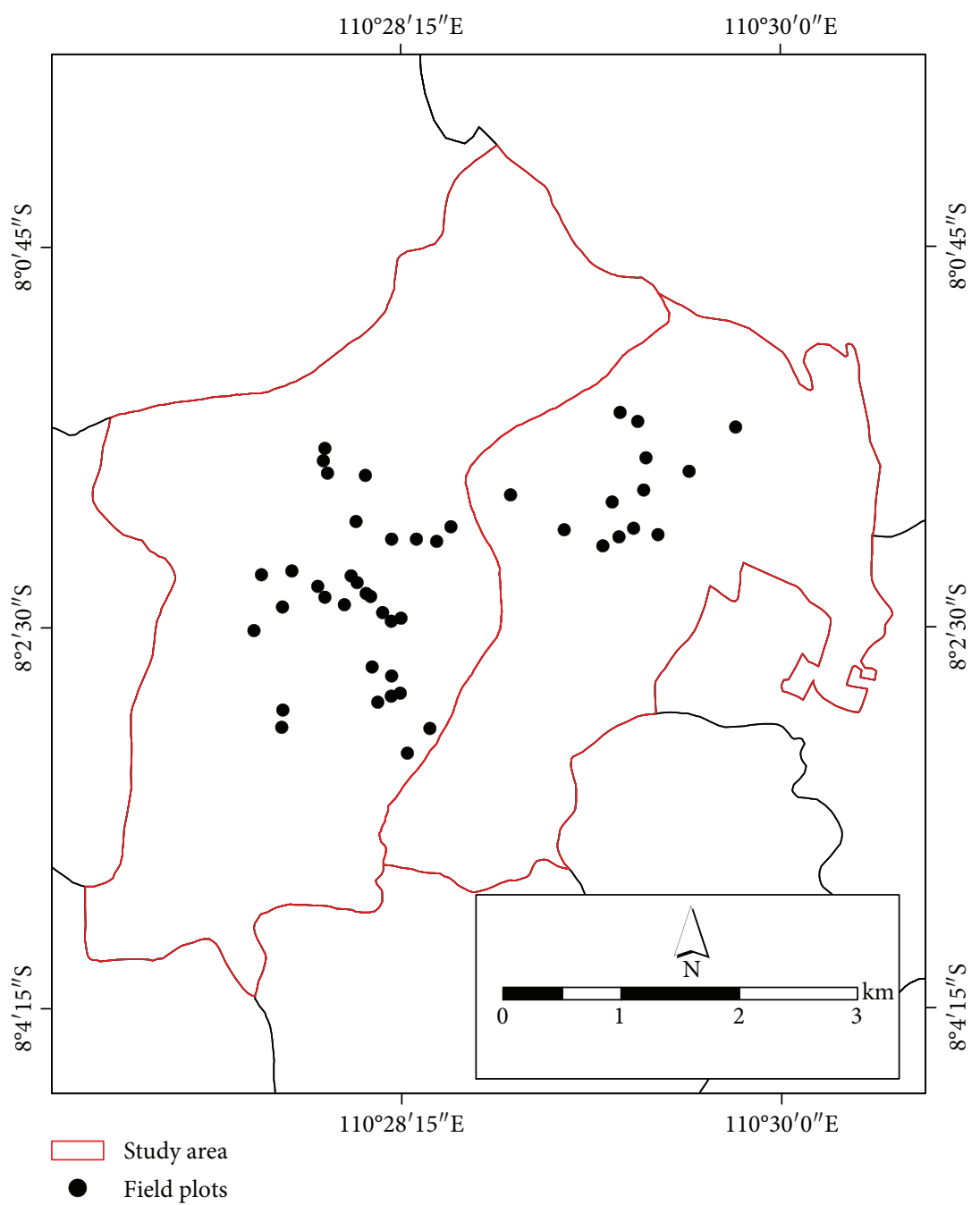

(a)

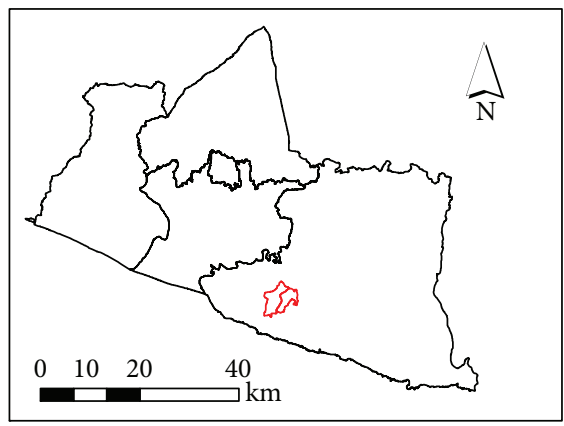

(b)

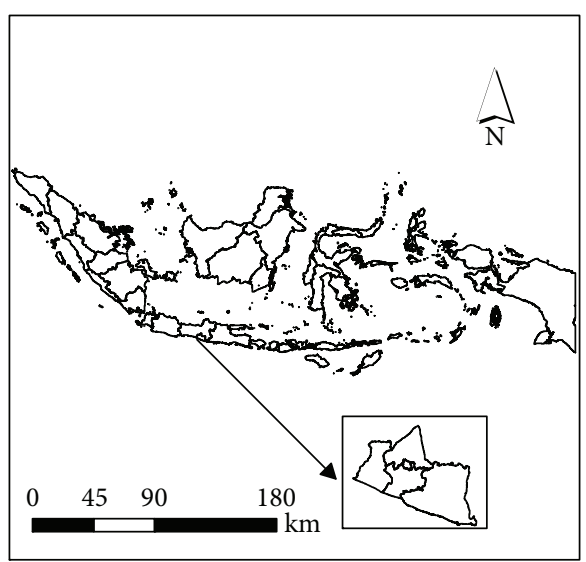

(c)

Figure 1: The study area: (a) map of Girisekar and Jetis; (b) the location of study area in Yogyakarta Province; (c) the location of Yogyakarta Province in the Indonesian map.

forest), hutan kemasyarakatan (community forest), hutan desa (village forest), kemitraan (partnership), hutan adat (customary forest), and hutan rakyat (private forest) [11]. Private forests are grown by farmers on their own land; others are facilitated by the government on natural forests. Private forests have a crucial role in the forest ecosystem especially since degradation of natural forests is continuing in Indonesia. Recognition of efforts to reduce greenhouse 
gas emission outside the natural forest including the private land (e.g., private forest) originated from the $16^{\text {th }}$ COP held in Mexico in 2010 resulted in a concept of Reducing Emissions from Deforestation and Forest Degradation (REDD) $+[12]$. A REDD scheme has encouraged United Nations Framework Convention on Climate Change (UNFCCC) members to establish a forest monitoring system by estimating forest carbon stock using a combination of forest inventory and remote sensing [13]. In addition, REDD+ in the private forest community provides a chance to gain international funding as long as they can increase carbon sink.

Considering the important role of the forest monitoring system, understanding the spatial distribution of aboveground biomass (AGB) is crucial [14]. AGB represents a majority of biomass values on the terrestrial ecosystem and is a useful parameter to measure the velocity of forest succession [15-17]. Furthermore, AGB also provides valuable information for forestry strategic planning [18]. AGB accumulation in the earth can be increased through expanding plantation areas such as private forests. Private forests have a potential to store AGB reaching a capacity of up to 300 tons/ha [19]. The number of private forests in Indonesia is likely to increase annually in accordance with the ambition of the government to expand social forestry areas at 12.7 million ha by 2019 [20]. The capabilities of remote sensing for assessing $\mathrm{AGB}$ have been tried in some types of forest in Indonesia like tropical forest [21] and mangrove [22]. However, information and methods for estimating AGB in private forests through remote sensing have not been treated in much detail.

Remote sensing based on vegetation indices has been widely used for estimating AGB. The vegetation index is enhanced by strong reflectance of near infrared (NIR) due to leaf internal scattering and high chlorophyll absorption by the red region of wavelength. One of the vegetation indices used to estimate biomass is the normalised difference vegetation index (NDVI) [23-26]. However, there are certain problems associated with the use of NDVI. One of these is that NDVI has a saturation problem particularly for dense vegetation which tends to have a high level of biomass [27, 28]. Utilisation of vegetation indices based on wavelengths located in the red edge is then a method that is proposed to overcome that problem [28].

Sentinel-2 is a new generation of multispectral satellite imagery that has been launched on 23 June 2015 by the European Space Agency (ESA). Sentinel-2 is a continuing image data from Landsat and SPOT, offering 13 spectral bands with 3 spatial resolutions $(10 \mathrm{~m}, 20 \mathrm{~m}$, and $60 \mathrm{~m})$, a wide swath of $290 \mathrm{~km}$, a radiometric resolution of 12 bits, and 5 days of revisit times by two satellites [29]. Utilisation of Sentinel-2 to assess AGB on private forests is interesting since the availability of red edge bands. Sentinel- 2 can be applied for mapping and monitoring forest areas and measuring biophysical structures of vegetation like AGB and leaf area index (LAI) $[30,31]$. However, there is lack of evidence about the utilisation of Sentinel-2 for predicting AGB on private forests.

Generally, the purpose of this study was to assess the potential of vegetation indices derived from Sentinel-2
TABLE 1: Allometric equations for calculation AGB in private forest.

\begin{tabular}{lcc}
\hline No. & Species & Allometric equation \\
\hline 1 & Teak (Tectona grandis) & $\mathrm{AGB}=0.0149\left(D^{2} H\right)^{1.0835}$ \\
2 & Acacia (Acacia auriculiformis) & $\mathrm{AGB}=0.0775\left(D^{2} H\right)^{0.9018}$ \\
3 & Mahogany (Swietenia mahagoni) & $\mathrm{AGB}=0.9029\left(D^{2} H\right)^{0.684}$ \\
4 & Other trees & $\mathrm{AGB}=0.0240\left(D^{2} H\right)^{0.7817}$ \\
\hline
\end{tabular}

Remarks: $D$ : stem diameter at breast height; $H$ : total tree height.

imagery for estimating AGB of private forests. Specifically, it is aimed at (1) modelling the relationship between vegetation indices resulted from Sentinel-2 and AGB derived from field measurement from private forests and (2) determining the AGB value on the Girisekar and Jetis private forest management unit. AGB from this study area then was compared with AGB from other forest types to evaluate the ability of private forests on the global carbon cycle and to support the Indonesian government mission for reducing $\mathrm{CO}_{2}$ emission.

\section{Materials and Methods}

2.1. Study Area. The study area lies in $8^{\circ} 01^{\prime} 15^{\prime \prime} \mathrm{N}$ and $110^{\circ} 27^{\prime}$ $30^{\prime \prime} \mathrm{E}$ (Figure 1). The area is located in the Jetis and Girisekar private forest management unit in Gunung Kidul Region, Yogyakarta Province, Indonesia. In terms of topography, Gunung Kidul is dominated by small limestone hills. Soils are shallow and prone to erosion. Annual precipitation is between 1700 and $2500 \mathrm{~mm}$ with around 122 rainy days [32].

In the past, massive forest loss, poverty, and soil erosion were common problems experienced by community living in Gunung Kidul [33]. This condition encouraged groups of farmers to start rehabilitation of the barren land through a planting tree program by the central government in 1963 [32]. Therefore, small-scale teak plantations of local farmers were widespread by the mid-1960s and became more attractive to the farmers in 1980 [34]. Nowadays, Gunung Kidul has become the main area of private forests in Indonesia with an annual production around 80,000 to $100,000 \mathrm{~m}^{3}$ [32]. There are several trees commonly planted by farmers such as teak (Tectona grandis), mahogany (Swietenia mahagoni), and earleaf acacia (Acacia auriculiformis).

2.2. Field Data Collection. Field data was taken in September 2017 and the end of November 2017. A total of 45 plots were set up. We used 30 plots for establishing the model and another 15 plots for validation. A stratified random sampling method was applied to select the plots based on accessibility, size, and type of trees. This sampling method was used to ascertain that areas with low and high AGB in community forests would be sampled. Each plot had a dimension of $20 \times 20 \mathrm{~m}$. In each plot, the height and diameter at breast height $(\mathrm{DBH})$ of trees with diameter $\geq 8 \mathrm{~cm}$ were measured. Based on the tree $\mathrm{DBH}$ and height, field AGB was calculated by applying specific allometric equations developed by Indonesian researchers [35] (Table 1). 
TABLE 2: Vegetation indices used to establish the AGB model.

\begin{tabular}{lccc}
\hline No. & Vegetation indices & Formula & References \\
\hline 1 & NDVI & $B 7-B 4 / B 7+B 4$ & {$[40]$} \\
2 & EVI & $G * B 7-B 4 / B 7+C 1 * B 4-C 2 * B 2+L$ & {$[41]$} \\
3 & Note: $C 1=6 ; C 2=7.5 ; L=1 ; G=2.5$ & {$[42]$} \\
4 & MSR & $(B 7 / B 4-1) /\left((B 7+B 4)^{1 / 2}+1\right)$ & {$[43]$} \\
5 & SR & $B 7 / B 4$ & {$[44]$} \\
6 & NDI 45 & $B 5-B 4 / B 5+B 4$ & {$[30]$} \\
7 & S2REP & $705+35 *((((B 7+B 4) / 2)-B 4) /(B 6-B 5))$ & {$[45]$} \\
\hline
\end{tabular}

2.3. Sentinel-2 Data Acquisition and Preprocessing. Sentinel-2 level 1-C data that covered the study area was acquired on 19 May 2017. The image was freely downloaded through the Copernicus Scientific Data Hub website. It had been scaled to top of atmosphere (TOA) level including orthorectification and spatial registration on a global reference system [29]. Sentinel-2 level 1-C was processed to level 2-A to gain a bottom of atmosphere- (BOA-) corrected reflectance image using the ATCOR algorithm through Sen2Cor plugin in Sentinel Application Platform (SNAP) software [36]. The image was resampled to $20 \mathrm{~m}$ spatial resolution using the nearest neighbour method to adjust the size of the sample plots. Finally, subsetting was done for the image to obtain the study area.

2.4. Private Forest Map. All land use patterns in the study area must be selected to classify the image data into land use and land cover categories. The land use pattern was classified into two groups such as private forest and nonprivate forest. Private forests are close to mixed plantation forests which are established by some trees and used for industrial and nonindustrial purposes [37]. These are planted by the farmers, and each farmer has a minimum of 0.25 ha of private forest land [38]. Nonprivate forests include state forest, settlement, agricultural land, water bodies, bare soil, road, and others. Contrary to private forests, state forests in our study area are established by the government and determined as production forests.

The private forest map of the study area was created from the Sentinel-2 image through the classification process. Supervised classification using maximum likelihood classification was employed to distinguish private forest and nonprivate forest. True colour combination from Sentinel-2 in particular bands 4,3 , and 2 in $10 \mathrm{~m}$ resolution was used to classify the image. Accuracy of the classified private forest map was assessed through the confusion matrix.

2.5. Modelling Relationship between Field AGB and Vegetation Indices. In this study, 30 field AGB and 7 vegetation indices were applied to assess the correlation between field AGB and vegetation indices shown in Table 2. Vegetation indices used in this study were divided into two. They were Sentinel-2 vegetation indices and traditional vegetation indices. Sentinel-2 vegetation indices are comprised of normalised difference index (NDI) 45 and Sentinel-2 red edge position (S2REP) whereas traditional indices involved NDVI, simple ratio (SR), modified simple ratio (MSR), green normalised difference vegetation index (GNDVI), and enhanced vegetation index (EVI). Traditional indices were selected based on simplicity and robustness. NDVI, SR, MSR, and GNDVI work through a simple algorithm, whereas GNDVI uses a green band instead of a red band. GNDVI has sensitivity on variation chlorophyll content. EVI is the robust index and has sensitivity to high biomass regions because it uses a correction factor to eliminate influence of aerosol and canopy background.

Coordinates of each plot were used to extract pixel values of vegetation indices using ArcGis 10.5. Linear regression was employed for exploring the relationship between AGB and vegetation indices. All vegetation indices were evaluated based on Pearson correlation coefficient $(r)$ and coefficient of determination $\left(R^{2}\right)$. The indices with high $r$ and $R^{2}$ were indicated to fit into AGB. Furthermore, AGB equation modelling was conducted by applying a stepwise linear regression method using SPSS version 17 by plotting AGB as a dependent variable and vegetation indices as independent variables. $R^{2}$, root mean square error (RMSE), and multicolinearity of variables, tolerance, and variance inflation factor (VIF) were calculated to confirm the reliability of the model [39].

2.6. Mapping the AGB over the Study Area. AGB stored in the study site could be calculated through an AGB map prediction. The model derived from stepwise linear regression was used to generate the map in ArcGis 10.5. A total of 15 sample plots observing AGB were plotted against 15 predicted AGB to validate the AGB map. $R^{2}$ and RMSE were calculated during this process (Figure 2).

The main purpose of community forest development is to meet the necessity of farmers; therefore, harvesting the intensity on the private forest is high. It may lead to unfavorable environmental benefits including a decrease in carbon stocks. Accordingly, AGB stored in our study area was compared to AGB in other types of forest.

\section{Results}

3.1. Private Forest Composition and Field AGB. The number of trees recorded in 45 (1.8 ha) sample plots was 1451 . A total of 8 species of trees were found, namely, Tectona 


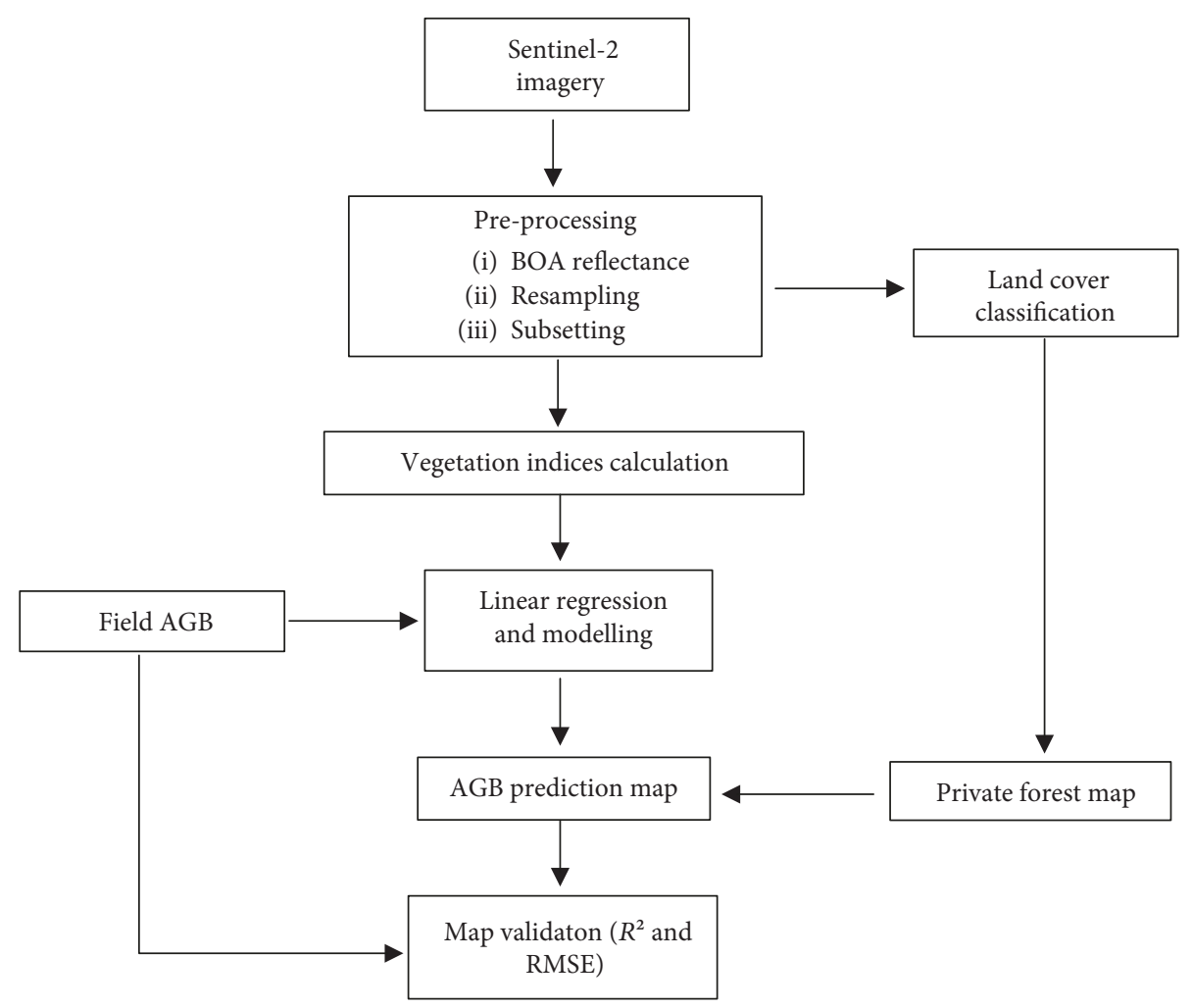

FIgURE 2: Flow chart of this study.

TABLE 3: Important value index for each species found in private forest.

\begin{tabular}{lcccccccc}
\hline No. & Species & Count & Density & RD (\%) & Frequency & RF (\%) & RD1 (\%) & IVI \\
\hline 1 & Tectona grandis & 891 & 19.80 & 63.82 & 0.93 & 42.43 & 87.00 & 193.25 \\
2 & Swietenia mahagoni & 302 & 6.71 & 20.04 & 0.58 & 26.26 & 8.29 & 54.59 \\
3 & Acacia auriculiformis & 232 & 5.16 & 14.45 & 0.40 & 18.18 & 4.59 & 37.22 \\
4 & Other trees & 26 & 0.58 & 1.69 & 0.29 & 13.13 & 0.12 & 14.94 \\
& Total & $\mathbf{1 4 5 1}$ & $\mathbf{3 2 . 2 4}$ & $\mathbf{1 0 0}$ & $\mathbf{2 . 2 0}$ & $\mathbf{1 0 0}$ & $\mathbf{1 0 0}$ & $\mathbf{3 0 0}$ \\
\hline
\end{tabular}

RD: relative density; RF: relative frequency; RD1: relative dominance. IVI is calculated from RD + RF + RD1 [46].

grandis, Swietenia mahagoni, Acacia auriculiformis, and other trees such as Samanea saman, Gnetum gnemon, Alstonia scholaris, Parkia speciosa, and Tamarindus indica. The dominant species in the Girisekar and Jetis forest management unit was Tectona grandis with a total of trees and important value index (IVI) of 891 and 193.25, respectively (Table 3). The IVI for Swietenia mahagoni and Acacia auriculiformis being the second and third dominant species were 54.59 and 37.22, respectively. Other trees group constituted the lowest in terms of IVI in private forest.

The mean of field AGB was $80 \mathrm{Mg} /$ ha, with minimum and maximum values of $21 \mathrm{Mg} / \mathrm{ha}$ and $226 \mathrm{Mg} / \mathrm{ha}$, respectively. Majority of AGB plots were spread evenly, ranging from 50 to $100 \mathrm{Mg} / \mathrm{ha}$. We found 8 sample plots with field AGB $<50$ $\mathrm{Mg} / \mathrm{ha}$ and few sample plots with field AGB $>150 \mathrm{Mg} / \mathrm{ha}$ (Figure 3).

3.2. Land Cover Classification Result. As many as 160 ground control sample points were selected for accuracy

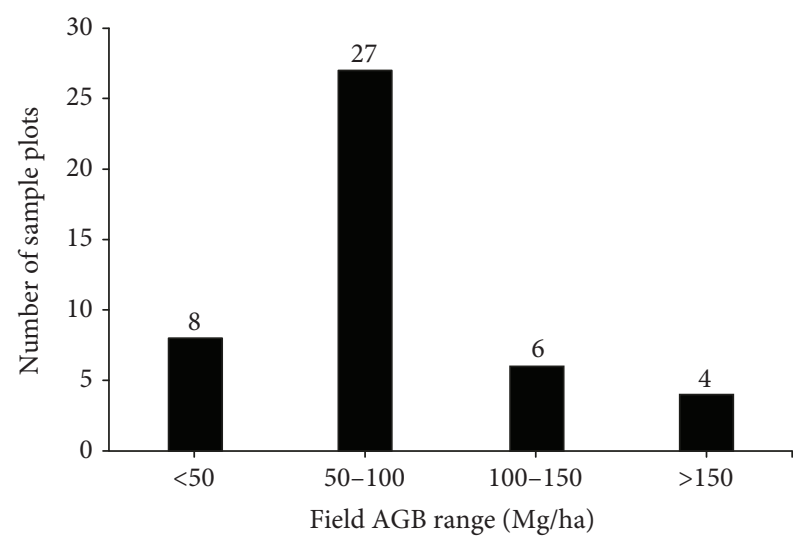

FIgure 3: Distribution of field AGB within the sample plot. 


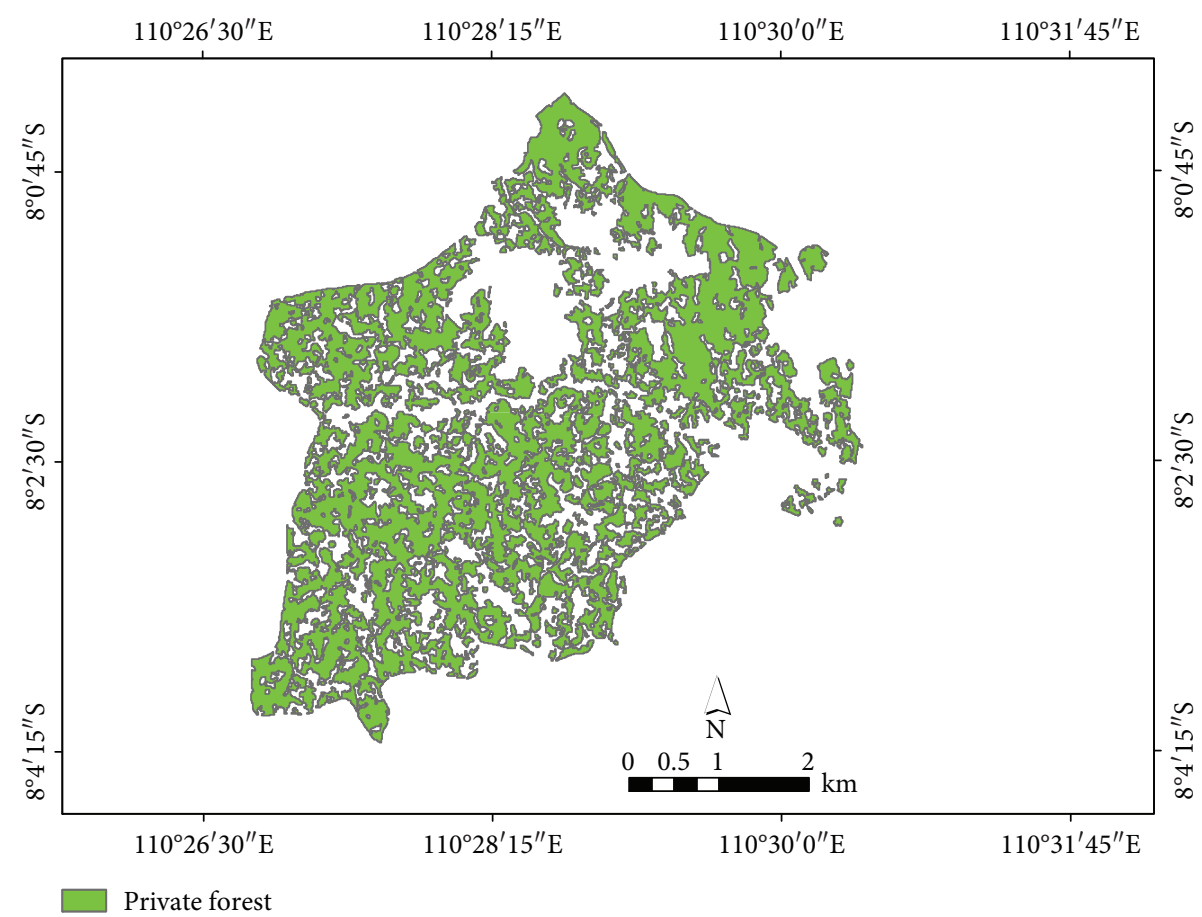

Figure 4: Girisekar and Jetis forest management unit map derived from supervised classification.

TABLE 4: Result of linear regression between vegetation indices and AGB.

\begin{tabular}{lccc}
\hline No. & Vegetation indices & $r$ & $R^{2}$ \\
\hline 1 & NDI45 & $0.89^{* *}$ & 0.79 \\
2 & MSR & $0.86^{* *}$ & 0.75 \\
3 & SR & $0.85^{* *}$ & 0.73 \\
4 & NDVI & $0.80^{* *}$ & 0.65 \\
5 & GNDVI & $0.70^{* *}$ & 0.49 \\
6 & EVI & $0.48^{* *}$ & 0.23 \\
7 & S2REP & $0.44^{* *}$ & 0.19 \\
\hline
\end{tabular}

** refers to a significant correlation at 0.01 level.

TABLE 5: Statistics of the AGB model.

\begin{tabular}{lccccc}
\hline Model variable & $R^{2}$ & RMSE & $p$ level & Tolerance & VIF \\
\hline$(n=30)$ & 0.81 & 19.44 & 0.001 & & \\
NDI45 & & & & 0.876 & 1.14 \\
EVI & & & & 0.876 & 1.14 \\
\hline
\end{tabular}

assessment of the Girisekar and Jetis private forest management unit map (Figure 4). User's accuracy of the private forest map was 95\%, while producer's and overall accuracies were $95 \%$ and $94 \%$, respectively. Based on the classification result, the large part of the Girisekar and Jetis private forest management unit was $1427 \mathrm{ha}$.

3.3. Modelling the Relationship between Vegetation Indices and Field $A G B$. The results of linear regression analysis between $A G B$ and vegetation indices derived from

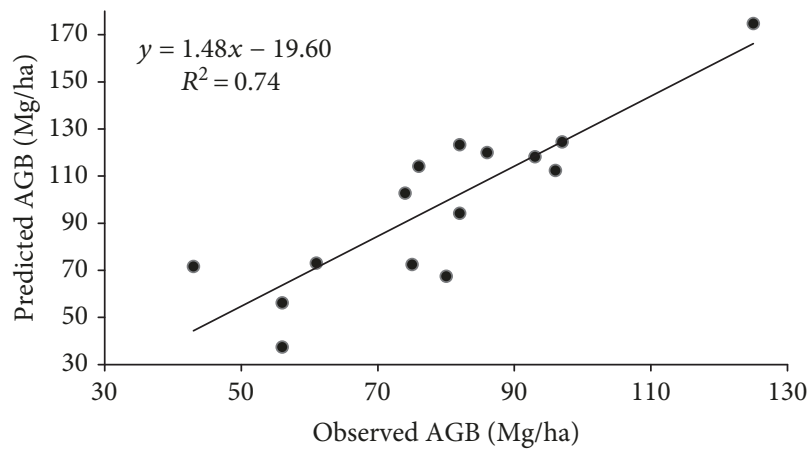

FIGURE 5: Scatter plot between predictive versus observed AGB.

Sentinel-2 are shown in Table 4 . The $r$ value of vegetation indices ranges from 0.44 to 0.89 , and $R^{2}$ varied between 0.19 and 0.79 . All vegetation indices showed a significant and positive correlation with AGB. NDI45 was the best vegetation index which corresponded to AGB $\left(r=0.89\right.$ and $\left.R^{2}=0.79\right)$ followed by MSR, SR, NDVI, GNDVI, EVI, and S2REP. All of the data for modelling is available in Supplementary Materials Section 1.

Based on stepwise linear regression, a model for estimating AGB in this study is expressed as

$$
\mathrm{AGB}=(537 * \mathrm{NDI} 45)+(158.42 * \mathrm{EVI})-353.66
$$

A developed model from NDI45 and EVI fitted for estimating AGB $\left(R^{2}=0.81, p<0.05\right)$ (Table 5). $R^{2} 81 \%$ meant that as much as $81 \%$ of AGB variability could be explained by the model. RMSE model was $19.44 \mathrm{Mg} / \mathrm{ha}$, 


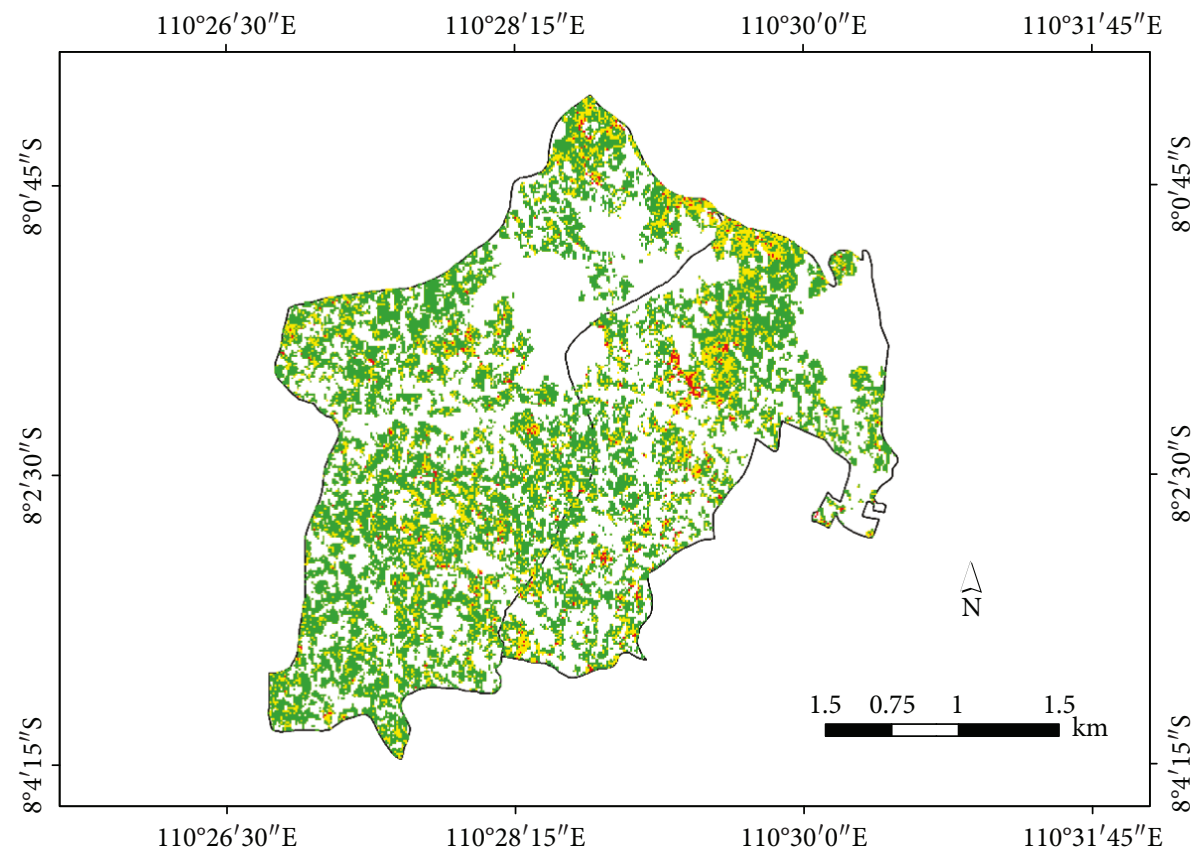

$$
\begin{aligned}
& \text { AGB (Mg/ha) } \\
& \square 0-100 \mathrm{Mg} / \mathrm{ha} \\
& \square 100-150 \mathrm{Mg} / \mathrm{ha} \\
& 150-248 \mathrm{Mg} / \mathrm{ha}
\end{aligned}
$$

Figure 6: The AGB map in Girisekar and Jetis private forest management unit.

and it was not a multicolinearity problem as the tolerance value was more than 0.1 and VIF was less than 10 .

3.4. AGB Map Prediction. Simple linear regression was developed to validate the AGB map from 15 plots. The correlation between the predicted and observed AGB gave a strong coefficient of determination, $R^{2}=0.74$. It indicated that approximately $74 \%$ of the observed AGB was explained by the predicted AGB according to this model (Figure 5). RMSE of the predicted and observed AGB values was $27 \mathrm{Mg} / \mathrm{ha}$. Data used to validate the AGB map is available in Supplementary Materials Section 2.

Figure 6 illustrates AGB map prediction resulted from the stepwise linear regression model between AGB field and vegetation indices (NDI45 and EVI). The number of AGB predicted for the Girisekar and Jetis private forest management unit from spatial analysis was $72.54 \mathrm{Mg} / \mathrm{ha}$. The AGB values varied from 0 to $248 \mathrm{Mg} / \mathrm{ha}$. Using the 0.5 conversion factor from biomass to carbon [47], the aboveground carbon biomass estimated from the study area was $36.27 \mathrm{Mg} / \mathrm{ha}$.

\section{Discussion}

Pearson correlation was employed for accessing the relationship between AGB and vegetation indices derived from the Sentinel-2 image. NDI45, MSR, SR, and NDVI had a strong correlation with AGB. NDVI is most widely used to measure biophysical properties of vegetation. Therefore, we compared it with other indices on this research. Once
NDI45 and NDVI were compared, NDI45 was more powerful than NDVI since NDVI had a saturation problem at a higher value of biomass (Figure 7). Saturation resulted from a slight change of the NDVI ratio due to high reflectance of NIR and decreasing red reflectance in an area with close canopy cover, and therefore, it would lead to a weak correlation with biomass [48]. Substitution of NIR to the red edge 1 on NDI45 at the Sentinel-2 image is able to improve the relationship between satellite data and biophysical properties of the vegetation. This is consistent with the result of Frampton et al. [30] where they found that the correlation of NDI45 was higher than NDVI on measuring canopy chlorophyll content (CCC). NDI45 created from Sentinel-2 B4 $(665 \mathrm{~nm})$ and red edge $1 \mathrm{~B} 5(705 \mathrm{~nm})$ is more robust in measuring biophysical parameters of vegetation than other band combination in Sentinel-2 [44].

MSR and SR outperformed NDVI in this study. It might be because the relationship of MSR and SR with biophysical properties of the vegetation was more linear than NDVI [30, 42]. NDVI is much affected by leaf optical and geometry effect from a sun view angle; hence, linearity to parameters of vegetation is lower than MSR [42]. EVI is more reliable than NDVI to measure AGB on dense vegetation because of its ability to reduce the effect of atmosphere and canopy background. However, EVI showed poor correlation to AGB in this research. A possible explanation is that the slope of the plots in the study area varies from flat to slightly inclined (slope range of the sample plots between $0^{\circ}$ and $19^{\circ}$ ). EVI is highly influenced by various terrain conditions $[49,50]$. The soil adjustment factor becomes the 

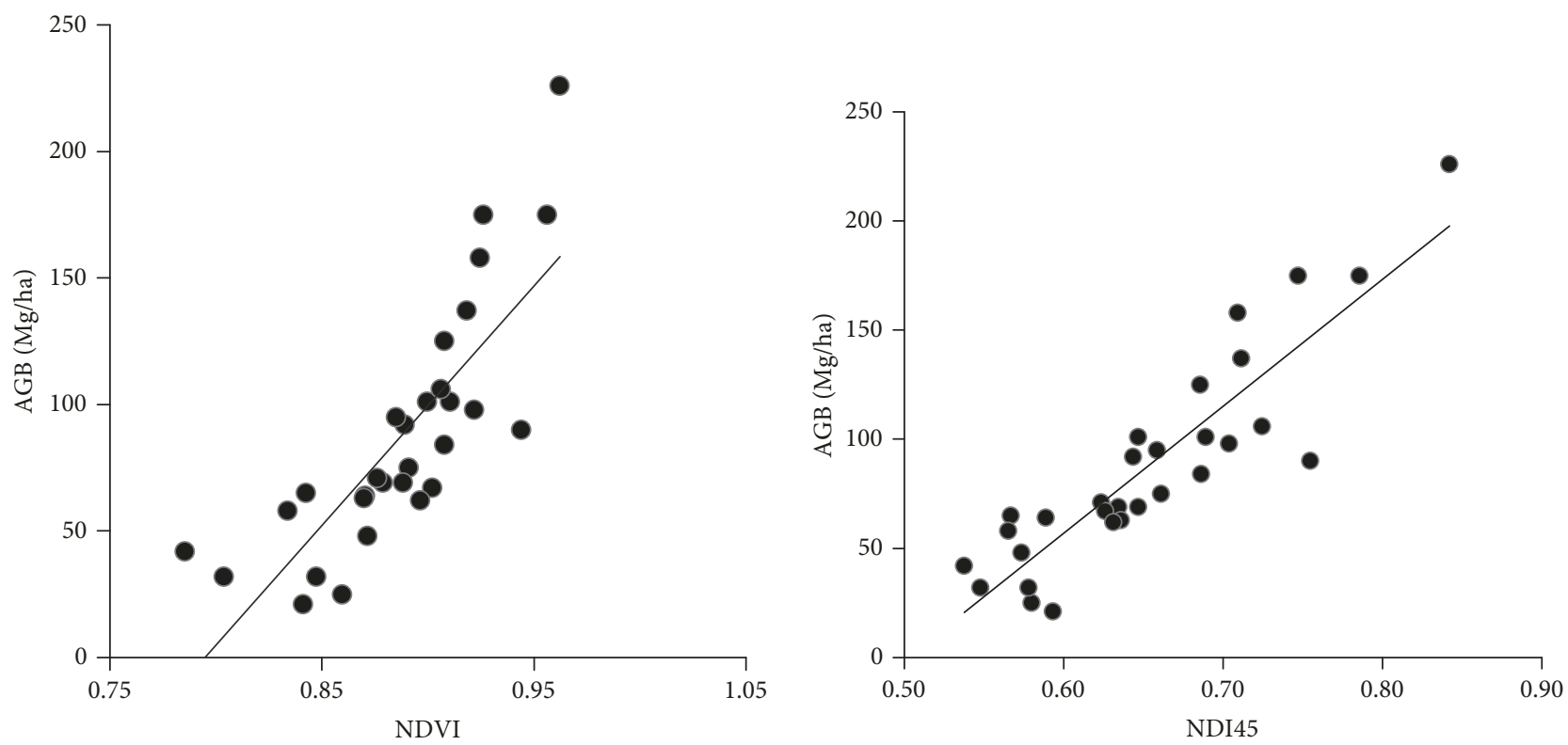

Figure 7: Scatter plot comparison between NDVI and NDI45 in estimating AGB.

TABLE 6: Comparison between AGB from private forest and other forest types; $1 \mathrm{Mg} / \mathrm{ha}=1$ ton/ha.

\begin{tabular}{lcccc}
\hline No. & Type of forest & AGB & Sensor & References \\
\hline 1 & Tropical & $382 \mathrm{Mg} / \mathrm{ha}$ & Lidar & Sentinel-2 \\
2 & Private & $72.54 \mathrm{Mg} / \mathrm{ha}$ & GeoEye-1 & This study \\
3 & Mangrove & $250.53 \mathrm{Mg} / \mathrm{ha}$ & QuickBird & {$[52]$} \\
4 & Mediterranean & $38 \mathrm{Ton} / \mathrm{ha}$ & ALOS PALSAR & {$[53]$} \\
5 & Deciduous & $58 \mathrm{Ton} / \mathrm{ha}$ & Landsat ETM+ & {$[54]$} \\
6 & Boreal & $39.5 \mathrm{Mg} / \mathrm{ha}$ & Landsat 8 and Radarsat-2 & {$[55]$} \\
7
\end{tabular}

limitation of EVI because it is very sensitive to topography than indices which are based on the simple ratio algorithm such as SR and NDVI [49].

Private forests are a potential source of AGB, having an important role in climate change mitigation. Therefore, comparing AGB from private forests and other forest types is imperative. AGB predicted in this study area was $72.54 \mathrm{Mg} / \mathrm{ha}$. The estimates of AGB given in the current study are higher than the estimates calculated from deciduous forests in India (58 Mg/ha) [54] (Table 6). It also almost doubles compared to the value from Mediterranean forests in Italy (38 Mg/ha) [53] and the AGB value from boreal forests in Alaska (39.5 Mg/ha) [55]. However, the current AGB is lower than the biomass of mangrove forests in Thailand (250.53 Mg/ha) [52], tropical forests in Borneo (382 Mg/ha) [51], and conifer broadleaf forests in China (106.45 Mg/ha) [54]. The AGB of tropical forests is higher than that of private forests because natural forests store a large amount of biomass on terrestrial ecosystems which accumulates over a long period of time. On the other hand, the sustainability of private forests depends on the success of the silviculture system and harvesting time by the farmers. Yet, AGB on private forests is still higher than AGB from some types of forest, and this is unexpected and suggests that private forests can be an alternative as biomass and carbon reservoir.

This research showed the potential of vegetation indices derived from Sentinel-2 to predict AGB on private forests. A number of researchers have reported AGB in plantation forests with different sensors [56-58]. For instance, Baig et al. [59] utilised ALOS-2 PALSAR to model and map Dalbergia sissoo forest plantation in Pakistan using nonlinear regression between field data and SAR backscatter. Dube and Mutanga [57] demonstrated the ability of WorldView-2 to retrieve AGB on Eucalyptus plantation in South Africa. However, the researchers have used mainly commercial satellite data instead of a cheap data source. This issue is problematic specially for developing countries or forest researchers who have limitation of budget. Therefore, making this methodology used in this research is very vital as it can address the cost issue as it uses free satellite image and is supported by opensource software, SNAP.

Furthermore, the sample plots of this study are limited as a result of accessibility and cost. Nevertheless, the sample plots were successful in establishing a model $\left(R^{2}=0.81\right)$ and predicted AGB map on the study area. The reason why the model on this research shows good performance can be 
attributed to the average of field AGB, which is $80 \mathrm{Mg} / \mathrm{ha}$ where only one sample plot had field AGB more than $200 \mathrm{Mg} / \mathrm{ha}$ and the others are below $200 \mathrm{Mg} / \mathrm{ha}$. It is too difficult to find areas with high AGB value on private forests because the farmers harvest mature trees. Therefore, it is plausible if majority of the sample plots would be only in low to medium AGB areas. Although NDVI was more saturated than NDI45, saturation data did not significantly influence our work due to limited sample plots in high biomass areas. In the case of Landsat TM, Lu et al. [60] stated that data saturation occurred when biomass reaches $100-150 \mathrm{Mg} / \mathrm{ha}$ depending on the complexity of the vegetation structure. There are abundant rooms for further research in evaluating the ability of Sentinel-2 imagery in tropical humid forests which tend to have a high value of biomass.

\section{Conclusion}

Sentinel-2 multispectral imagery can be utilised to estimate AGB on the Girisekar and Jetis private forest management unit. Vegetation indices were obtained from the Sentinel-2 data image. Normalised difference index (NDI) 45, which is established from red and red-edge 1 bands, had a strong correlation with $\mathrm{AGB}$ in comparison with other indices. The study demonstrated that the AGB model derived from stepwise linear regression was robust $\left(R^{2}=0.81\right) . R^{2}$ between observed and predicted AGB from the Sentinel-2 private forest model was 0.74 indicating that $A G B$ can be predicted with high accuracy using remote sensing data. The AGB predicted in this research is higher than the AGB from some types of forest like deciduous and Mediterranean. The result suggested that private forests are a reliable source to reducing $\mathrm{CO}_{2}$ emission.

\section{Data Availability}

The data used in this study can be divided by two. They are spatial and field data. Field data was taken from the field via direct measurement, and spatial data was captured from Sentinel-2 satellite image. All of the data then was compared through statistical analysis to achieve the goal of this study. The spatial and field data are included in Supplementary Information files. If there is any doubt about the data, everyone can contact the corresponding author.

\section{Conflicts of Interest}

The authors declare that they have no conflicts of interest.

\section{Acknowledgments}

Prince of Songkla University (PSU) has accorded technical support and funding in the accomplishment of this study through Thailand's Education Hub for ASEAN Countries (TEH-AC) program. We thank the Girisekar and Jetis private forest owner for allowing data collection.

\section{Supplementary Materials}

The data aforementioned is used to correlate between AGB and the vegetation indices via linear regression. The data is also used to establish the AGB prediction model through multilinear regression. AGB is a field data which is collected through plot measurement in the private forest. Vegetation indices are derived from a Sentinel-2 satellite image through mathematical function. The UTM coordinates are coordinates of each sample plot in the field. The coordinates are used to connect between field data and vegetation index values. The results of this data can be seen in Modelling the Relationship between Vegetation Indices and Field AGB in this manuscript. Section 2: In this section, we provide data for AGB map validation. Output of this research is an AGB map which represents real AGB in the study area. The AGB map was produced from mapping software using the AGB prediction model in Section 1. To ensure the reliability of our map, it has to be validated. For this analysis, the data can be divided into two groups: observed and predicted AGB. Each group has fifteen data. Observed AGB was real $A G B$ and were taken from plot measurement in the private forest while predicted AGB was AGB from the predicted map which had the same coordinate, having observed AGB. The coefficient of determination $\left(R^{2}\right)$ and root mean square error (RMSE) were used to validate the performance of the model. The results of AGB map validation can be seen in AGB Map Prediction in this manuscript. (Supplementary Materials)

\section{References}

[1] A. E. Russon, A. Erman, and R. Dennis, "The population and distribution of orangutans (Pongo pygmaeus pygmaeus) in and around the Danau Sentarum Wildlife Reserve, West Kalimantan, Indonesia," Biological Conservation, vol. 97, no. 1, pp. 21-28, 2001.

[2] T. G. O’Brien and M. F. Kinnaird, "Caffeine and conservation," Science, vol. 300, no. 5619, pp. 587-587, 2003.

[3] H. T. Wibisono and W. Pusparini, "Sumatran tiger (Panthera tigris sumatrae): a review of conservation status," Integrative Zoology, vol. 5, no. 4, pp. 313-323, 2010.

[4] B. Loken, S. Spehar, and Y. Rayadin, "Terrestriality in the bornean orangutan (Pongo pygmaeus morio) and implications for their ecology and conservation," American Journal of Primatology, vol. 75, no. 11, pp. 1129-1138, 2013.

[5] S. A. Abood, J. S. H. Lee, Z. Burivalova, J. Garcia-Ulloa, and L. P. Koh, "Relative contributions of the logging, fiber, oil palm, and mining industries to forest loss in Indonesia," Conservation Letters, vol. 8, no. 1, pp. 58-67, 2015.

[6] B. A. Margono, S. Turubanova, I. Zhuravleva et al., "Mapping and monitoring deforestation and forest degradation in Sumatra (Indonesia) using Landsat time series data sets from 1990 to 2010," Environmental Research Letters, vol. 7, no. 3, article 034010, 2012.

[7] D. O. Fuller, T. C. Jessup, and A. Salim, "Loss of forest cover in Kalimantan, Indonesia, since the 1997-1998 El Niño," Conservation Biology, vol. 18, no. 1, pp. 249-254, 2004.

[8] R. Tsujino, T. Yumoto, S. Kitamura, I. Djamaluddin, and D. Darnaedi, "History of forest loss and degradation in 
Indonesia," Land Use Policy, vol. 57, Supplement C, pp. 335$347,2016$.

[9] World bank, Indonesia and Climate Charge: Current Status and Policies, 2007, September 2017, https://siteresources .worldbank.org/INTINDONESIA/Resources/Environment/ ClimateChange_Full_EN.pdf.

[10] Republic of Indonesia, Intended Nationally Contribution Republik of Indonesia, 2015, April 2017, http://www4.unfccc .int/submissions/INDC/Published\%20Documents/Indonesia/ 1/INDC_REPUBLIC\%20OF\%20INDONESIA.pdf.

[11] Republic of Indonesia, Peraturan Menteri Lingkungan Hidup dan Kehutanan Republik Indonesia Nomor P.83/MenLHK/Setjen/Kum.1/10/2016 tentang Perhutanan Sosial, 2016, July 2017, http://www.forda-mof.org/files/P.83_2016.pdf.

[12] L. Goers, J. Lawson, and E. Garen, "Economic drivers of tropical deforestation for agriculture," in Managing Forest Carbon in a Changing Climate, M. Ashton, M. Tyrrell, D. Spalding, and B. Gentry, Eds., pp. 305-320, Springer, Dordrecht, 2012.

[13] T. Tokola, "Remote sensing concepts and their applicability in REDD+ monitoring," Current Forestry Reports, vol. 1, no. 4, pp. 252-260, 2015.

[14] R. A. Houghton, "Aboveground forest biomass and the global carbon balance," Global Change Biology, vol. 11, no. 6, pp. 945-958, 2005.

[15] H. K. Gibbs, S. Brown, J. O. Niles, and J. A. Foley, "Monitoring and estimating tropical forest carbon stocks: making REDD a reality," Environmental Research Letters, vol. 2, no. 4, article 045023, 2007.

[16] K. Mokany, R. J. Raison, and A. S. Prokushkin, "Critical analysis of root: shoot ratios in terrestrial biomes," Global Change Biology, vol. 12, no. 1, pp. 84-96, 2006.

[17] D. M. A. Rozendaal, R. L. Chazdon, F. Arreola-Villa et al., "Demographic drivers of aboveground biomass dynamics during secondary succession in neotropical dry and wet forests," Ecosystems, vol. 20, no. 2, pp. 340-353, 2017.

[18] H. Gallaun, G. Zanchi, G.-J. Nabuurs, G. Hengeveld, M. Schardt, and P. J. Verkerk, "EU-wide maps of growing stock and above-ground biomass in forests based on remote sensing and field measurements," Forest Ecology and Management, vol. 260, no. 3, pp. 252-261, 2010.

[19] M. Wilnhammer, A. Rothe, W. Weis, and S. Wittkopf, "Estimating forest biomass supply from private forest owners: a case study from Southern Germany," Biomass Bioenergy, vol. 47, Supplement C, pp. 177-187, 2012.

[20] T. Santika, E. Meijaard, S. Budiharta et al., "Community forest management in Indonesia: avoided deforestation in the context of anthropogenic and climate complexities," Global Environmental Change, vol. 46, pp. 60-71, 2017.

[21] A. Wijaya, S. Kusnadi, R. Gloaguen, and H. Heilmeier, "Improved strategy for estimating stem volume and forest biomass using moderate resolution remote sensing data and GIS," Journal of Forest Research, vol. 21, no. 1, pp. 1-12, 2010.

[22] P. Wicaksono, "Mangrove above-ground carbon stock mapping of multi-resolution passive remote-sensing systems," International Journal of Remote Sensing, vol. 38, no. 6, pp. 1551-1578, 2017.

[23] C. J. Tucker, C. L. Vanpraet, M. J. Sharman, and G. Van Ittersum, "Satellite remote sensing of total herbaceous biomass production in the senegalese sahel: 1980-1984," Remote Sensing of Environment, vol. 17, no. 3, pp. 233-249, 1985.
[24] N. I. Gasparri, M. G. Parmuchi, J. Bono, H. Karszenbaum, and C. L. Montenegro, "Assessing multi-temporal Landsat 7 ETM + images for estimating above-ground biomass in subtropical dry forests of Argentina," Journal of Arid Environments, vol. 74, no. 10, pp. 1262-1270, 2010.

[25] A. A. Wani, P. K. Joshi, and O. Singh, "Estimating biomass and carbon mitigation of temperate coniferous forests using spectral modeling and field inventory data," Ecological Informatics, vol. 25, Supplement C, pp. 63-70, 2015.

[26] C. Huang, X. Ye, C. Deng, Z. Zhang, and Z. Wan, "Mapping above-ground biomass by integrating optical and SAR imagery: a case study of Xixi National Wetland Park, China," Remote Sensing, vol. 8, no. 8, p. 647, 2016.

[27] A. R. Huete, H. Q. Liu, K. Batchily, and W. van Leeuwen, "A comparison of vegetation indices over a global set of TM images for EOS-MODIS," Remote Sensing of Environment, vol. 59, no. 3, pp. 440-451, 1997.

[28] O. Mutanga and A. K. Skidmore, "Narrow band vegetation indices overcome the saturation problem in biomass estimation," International Journal of Remote Sensing, vol. 25, no. 19, pp. 3999-4014, 2004.

[29] Sentinel-2_Team, Sentinel-2 User Hand Book, Europian Space Agency, 2015.

[30] W. J. Frampton, J. Dash, G. Watmough, and E. J. Milton, "Evaluating the capabilities of Sentinel-2 for quantitative estimation of biophysical variables in vegetation," ISPRS Journal of Photogrammetry and Remote Sensing, vol. 82, Supplement C, pp. 83-92, 2013.

[31] T. Majasalmi and M. Rautiainen, "The potential of Sentinel-2 data for estimating biophysical variables in a boreal forest: a simulation study," Remote Sensing Letters, vol. 7, no. 5, pp. 427-436, 2016.

[32] A. Hinrichs, D. Muhtaman, and N. Irianto, Forest Certification on Community Land in Indonesia, Deutsche Gesellschaft für Technische Zusammenarbeit (GTZ), Jakarta, Indonesia, 2008.

[33] J. W. Nibbering, "Tree planting on deforested farmlands, Sewu Hills, Java, Indonesia: impact of economic and institutional changes," Agroforestry Systems, vol. 46, no. 1, pp. 65-82, 1999.

[34] D. Rohadi et al., Improving Economic Outcomes for Smallholders Growing Teak in Agroforestry Systems in Indonesia, Australian Centre for International Agriculture Research, Canberra, 2012.

[35] R. H. Purwanto, R. Rohman, A. Maryudi, T. Yuwono, D. B. Permadi, and M. Sanjaya, "Potensi Biomasa dan Simpanan Karbon Jenis-jenis Tanaman Berkayu di Hutan Rakyat Desa Nglanggeran, Gunungkidul, Daerah Istimewa Yogyakarta," Jurnal Ilmu Kehutanan, vol. 6, no. 2, pp. 128-141, 2015.

[36] J. Louis, V. Debaecker, B. Pflug et al., "Sentinel-2 Sen2Cor: L2A processor for users," in Living Planet Symposium, p. 91, Prague, Czech Republic, May 2016.

[37] T. J. Wormald, Mixed and Pure Forest Plantations in the Tropics and Sub Tropics, FAO, Rome, 1992.

[38] Republic of Indonesia, Statistik Lingkungan hidup dan kehutanan tahun 2016, 2017, August 2018, http://www.menlhk.go.id/ downlot.php?file=Statistik_KLHK_2016.pdf.

[39] S. Eckert, "Improved forest biomass and carbon estimations using texture measures from WorldView-2 satellite data," Remote Sensing, vol. 4, no. 4, pp. 810-829, 2012.

[40] C. J. Tucker, "Red and photographic infrared linear combinations for monitoring vegetation," Remote Sensing of Environment, vol. 8, no. 2, pp. 127-150, 1979. 
[41] A. Huete, K. Didan, T. Miura, E. P. Rodriguez, X. Gao, and L. G. Ferreira, "Overview of the radiometric and biophysical performance of the MODIS vegetation indices," Remote Sensing of Environment, vol. 83, no. 1-2, pp. 195-213, 2002.

[42] J. M. Chen, "Evaluation of vegetation indices and a modified simple ratio for boreal applications," Canadian Journal of Remote Sensing, vol. 22, no. 3, pp. 229-242, 1996.

[43] C. F. Jordan, "Derivation of leaf-area index from quality of light on the Forest floor," Ecology, vol. 50, no. 4, pp. 663-666, 1969.

[44] J. Delegido, J. Verrelst, L. Alonso, and J. Moreno, "Evaluation of Sentinel-2 red-edge bands for empirical estimation of green LAI and chlorophyll content," Sensors, vol. 11, no. 7, pp. 70637081, 2011.

[45] A. A. Gitelson, Y. J. Kaufman, and M. N. Merzlyak, "Use of a green channel in remote sensing of global vegetation from EOS-MODIS," Remote Sensing of Environment, vol. 58, no. 3, pp. 289-298, 1996.

[46] J. T. Curtis and R. P. McIntosh, "The interrelations of certain analytic and synthetic phytosociological characters," Ecology, vol. 31, no. 3, pp. 434-455, 1950.

[47] S. Brown and A. E. Lugo, "The storage and production of organic matter in tropical forests and their role in the global carbon cycle," Biotropica, vol. 14, no. 3, pp. 161-187, 1982.

[48] P. S. Thenkabail, R. B. Smith, and E. De Pauw, "Hyperspectral vegetation indices and their relationships with agricultural crop characteristics," Remote Sensing of Environment, vol. 71, no. 2, pp. 158-182, 2000.

[49] B. Matsushita, W. Yang, J. Chen, Y. Onda, and G. Qiu, "Sensitivity of the enhanced vegetation index (EVI) and normalized difference vegetation index (NDVI) to topographic effects: a case study in high-density cypress forest," Sensors, vol. 7, no. 11, pp. 2636-2651, 2007.

[50] E. L. Garroutte, A. J. Hansen, and R. L. Lawrence, "Using NDVI and EVI to map spatiotemporal variation in the biomass and quality of forage for migratory elk in the greater yellowstone ecosystem," Remote Sensing, vol. 8, no. 5, p. 404, 2016.

[51] K. Ioki, S. Tsuyuki, Y. Hirata et al., "Estimating above-ground biomass of tropical rainforest of different degradation levels in Northern Borneo using airborne LiDAR," Forest Ecology and Management, vol. 328, Supplement C, pp. 335-341, 2014.

[52] N. R. A. Jachowski, M. S. Y. Quak, D. A. Friess, D. Duangnamon, E. L. Webb, and A. D. Ziegler, "Mangrove biomass estimation in Southwest Thailand using machine learning," Applied Geography, vol. 45, pp. 311-321, 2013.

[53] E. Santi, C. Tarantino, V. Amici et al., "Fine-scale spatial distribution of biomass using satellite images," Journal of Ecology and The Natural Environment, vol. 6, no. 2, pp. 75-86, 2014.

[54] K. C. Thumaty, R. Fararoda, S. Middinti, R. Gopalakrishnan, C. S. Jha, and V. K. Dadhwal, "Estimation of above ground biomass for central Indian deciduous forests using ALOS PALSAR L-band data," Journal of the Indian Society of Remote Sensing, vol. 44, no. 1, pp. 31-39, 2016.

[55] L. Ji, B. K. Wylie, D. R. N. Brown et al., "Spatially explicit estimation of aboveground boreal forest biomass in the Yukon River Basin, Alaska," International Journal of Remote Sensing, vol. 36, no. 4, pp. 939-953, 2015.

[56] Z. Shao and L. Zhang, "Estimating forest aboveground biomass by combining optical and SAR data: a case study in Genhe, Inner Mongolia, China," Sensors, vol. 16, no. 6, 2016.
[57] T. Dube and O. Mutanga, "The impact of integrating WorldView-2 sensor and environmental variables in estimating plantation forest species aboveground biomass and carbon stocks in uMgeni Catchment, South Africa," ISPRS Journal of Photogrammetry and Remote Sensing, vol. 119, pp. 415-425, 2016.

[58] E. W. Maina, P. A. Odera, and M. J. Kinyanjui, "Estimation of above ground biomass in forests using Alos Palsar data in Kericho and Aberdare ranges," Open Journal of Forestry, vol. 7, no. 2, pp. 79-96, 2017.

[59] S. Baig, W. A. Qazi, A. M. Akhtar et al., “Above ground biomass estimation of Dalbergia sissoo forest plantation from dual-polarized ALOS-2 PALSAR data," Canadian Journal of Remote Sensing, vol. 43, no. 3, pp. 297-308, 2017.

[60] D. Lu, Q. Chen, G. Wang, L. Liu, G. Li, and E. Moran, “A survey of remote sensing-based aboveground biomass estimation methods in forest ecosystems," International Journal of Digital Earth, vol. 9, no. 1, pp. 63-105, 2016. 


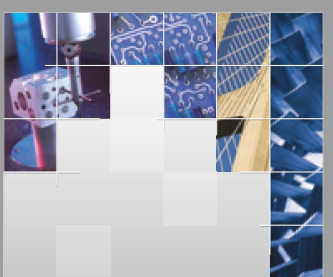

\section{Enfincering}
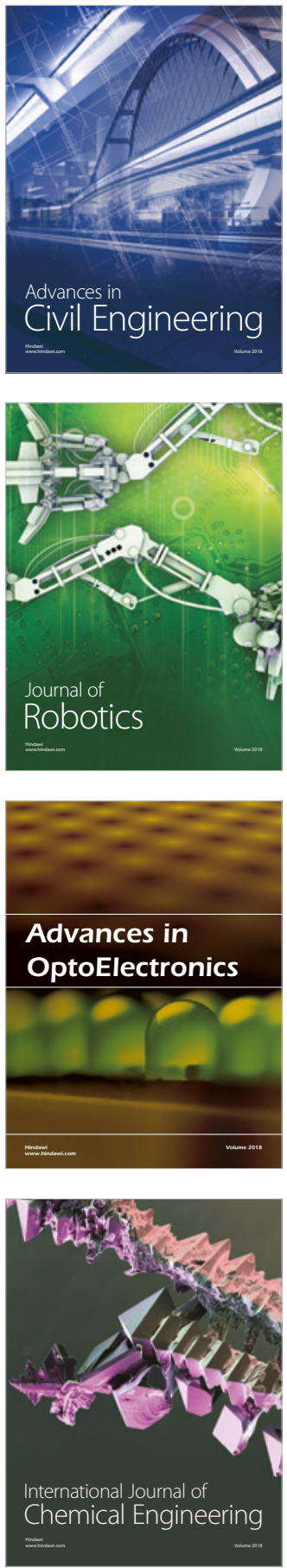

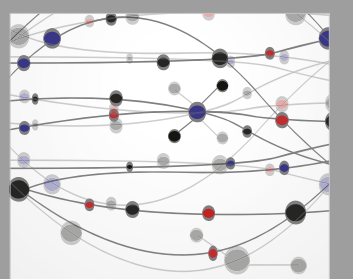

\section{Rotating \\ Machinery}

The Scientific World Journal

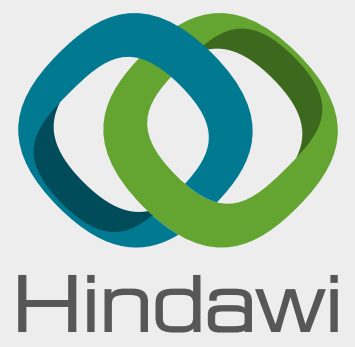

Submit your manuscripts at

www.hindawi.com
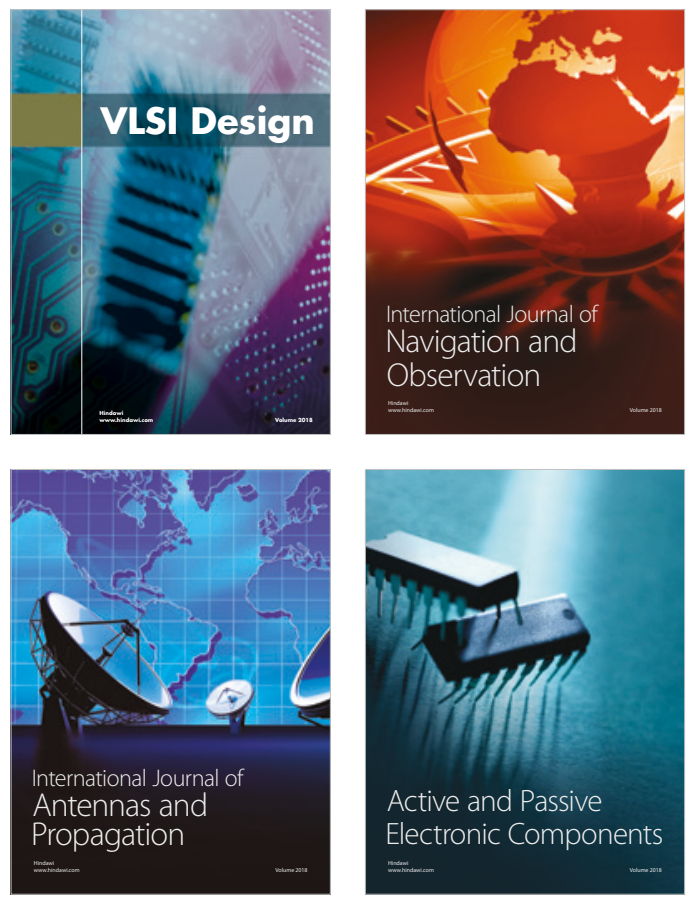
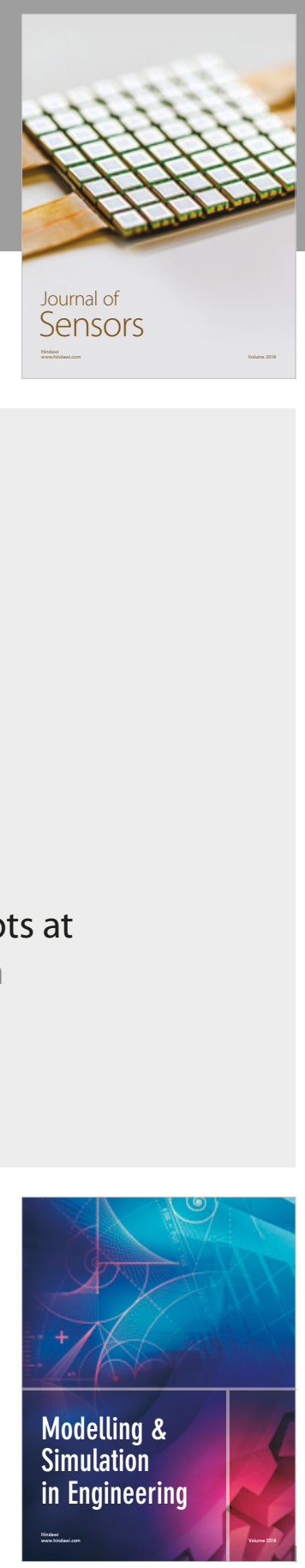

\section{Advances \\ Multimedia}
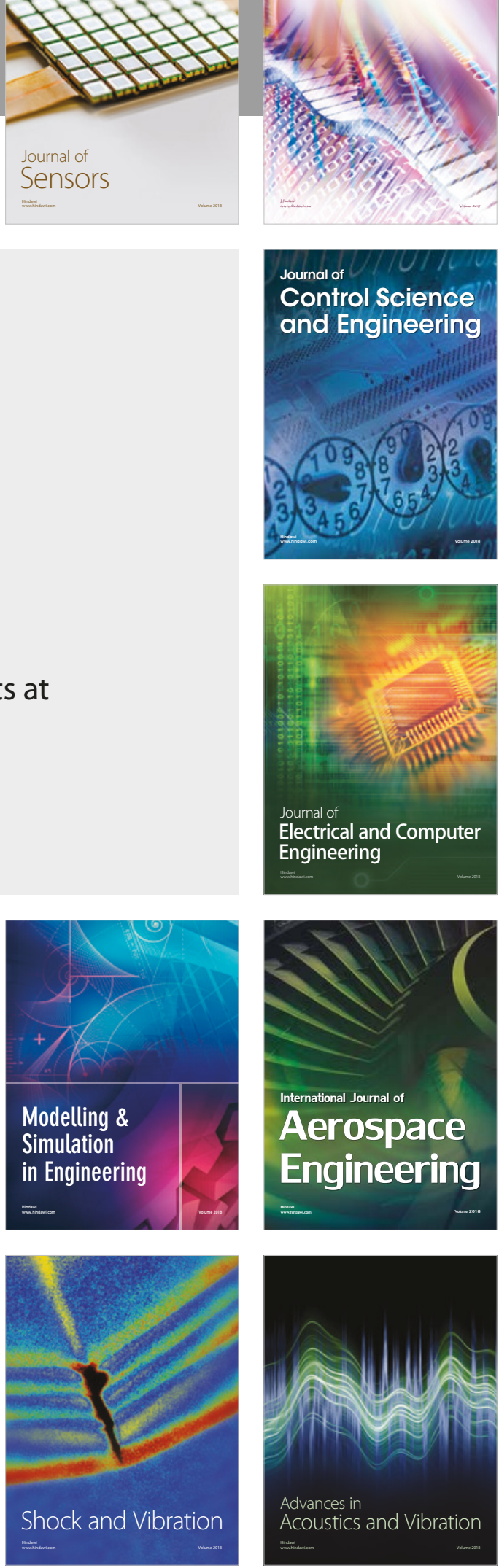